\title{
Production of External Quality Assessment Materials for Anti-Müllerian Hormone Assay
}

\author{
Anna Lee and Hee-Jung Kim \\ Department of Laboratory Medicine, Seoul Clinical Laboratories, Yongin, Korea
}

\section{Corresponding author:}

Anna Lee

Department of Laboratory Medicine, Seoul Clinical Laboratories, 13 Heungdeok 1-ro, Giheung-gu, Yongin 16954, Korea

Tel +82-2-330-2202

Fax +82-2-790-6509

E-mail anlee@scllab.co.kr

Received: June 17, 2020

Revised: August 14, 2020

Accepted: August 21, 2020
This is an Open Access article distributed under the terms of the Creative Commons Attribution Non-Commercial License (http://creativecommons.org/licenses/ by-nc/4.0) which permits unrestricted non-commercial use, distribution, and reproduction in any medium, provided the original work is properly cited.
Background: Anti-Müllerian hormone (AMH) is regarded as a sensitive and specific biomarker for assessing the ovarian reserve and has gained widespread clinical use. However, discrepancies between methods, different reference values, and inter-laboratory variation complicate the interpretation of $A M H$ values and their clinical implications. To resolve these problems, external quality assessment (EQA) is important for standardizing AMH assays, thereby ensuring accurate and precise results. To conduct an EQA program, a large amount of quality control (QC) material is required. This study aimed to produce AMH QC materials for an EQA program and evaluate their homogeneity and stability.

Methods: QC materials for three different concentrations of AMH were produced from the collected remnant sera of 632 patients in whom AMH assays were performed. These materials were evaluated for homogeneity between vials and short-term stability over 7 days at three different storage conditions.

Results: The total coefficient of variation of the AMH QC materials at the three different concentrations ranged $2.09 \%-2.48 \%$. No significant inhomogeneity was noted between vials; therefore, the samples were considered to be homogenous. With respect to short-term stability, three levels of AMH QC materials were found to be stable for at least 7 days when refrigerated or frozen condition.

Conclusions: The AMH QC materials produced from remnant sera were found to be homogenous between vials and remained stable in a refrigerated and frozen condition for at least 7 days. The findings of this study may be practically applied for producing AMH EQA materials.

\section{(Lab Med Qual Assur 2020;42:211-217)}

Key Words Anti-Müllerian hormone, Ovarian reserve, External quality assessment, Quality control

\section{서론}

항뮬러관호르몬(Anti-Müllerian hormone, AMH)은 난소 내 전동난포(pre-antral follicle) 및 작은 동난포(antral follicle) 의 과립층세포에서 생성되는 transforming growth factor- $\beta$ superfamily에 속하는 당단백이다. AMH는 뮬러관 억제물
질(Müllerian inhibiting substance)로, 배아기 성 분화(sex differentiation)에 중요한 역할을 하는 것으로 알려져 있다[1]. $\mathrm{AMH}$ 검사는 최근 약 20년 사이에 난소 예비능과 난포 활성도 를 반영하는 혈청검사 중 가장 우수한 지표로 인정받아 체외수 정 시 난소자극반응 예측 목적뿐 아니라 다낭성 난소증후군의 진 단, 폐경의 예측 목적 등을 위하여 임상적으로 광범위하게 활용되 
고 있다[2-4]. AMH 농도는 난소 예비능을 보기 위하여 기존에 사 용하고 있던 생리주기 2일 또는 3일의 기저 follicle-stimulating hormone $(\mathrm{FSH})$ 농도보다 유용하며, 동난포 수와의 상관성이 우 수하여 그 임상적 효용성이 인정되었고, 주기 내(intracycle), 주 기 간(intercycle) 농도가 비교적 일정하게 유지되어 여성의 월경 주기와 무관하게 검체 채취를 할 수 있다는 장점이 있다[2,3].

$\mathrm{AMH}$ 는 난소의 과배란 유도 시 반응 및 난소능력 예측, 폐경 유 무의 판단을 위한 직접지표로서 안전하고 유효한 검사로 평가되어 2009년 8월 27일 신의료기술평가 결과가 고시되었고(보건복지부 고시 제2009-160호), 또한 2019년 11월 4일 부로 요양급여 적용 고시가 발표되었다(보건복지부 고시 제2019-244호).

위와 같은 다양한 임상상황에서 $\mathrm{AMH}$ 농도가 치료방향의 결 정과 진단에 중요한 지표가 되므로 외부정도관리를 통하여 검 사 정확도가 관리될 필요가 있다. 호주의 경우 Royal College of Pathologists of Australasia Quality Assurance Programs에 서 2011년부터, 미국의 경우 College of American Pathologists 에서 2014년부터 AMH 외부신빙도조사 프로그램을 운용하고 있 고, 국내에서는 $\mathrm{AMH}$ 검사에 대한 신빙도조사 프로그램이 2020년 상반기에 처음으로 개설되었다. 저자들은 환자의 잔여 검체를 활 용하여 최근 난소능력 반영지표로서 임상적 사용이 증가되고 있는 $\mathrm{AMH}$ 검사에 대한 외부신빙도조사물질의 제조방법을 확립하고자 본 연구를 시행하였다.

\section{재료 및 방법}

\section{1. 대상}

2018년 6월 1일부터 9월 31일까지 (재)서울의과학연구소에 $\mathrm{AMH}$ 검사가 의뢰된 환자의 검사 완료 후 잔여 혈청을 수집하 였다. B형 간염 표면항원, C형 간염 항체 및 human immunodeficiency virus (HIV) 항체검사를 실시하고, 세 검사 모두 음성 인 잔여 혈청 632개를 수집하여 $\mathrm{AMH}$ 농도에 따라 $1.0 \mathrm{ng} / \mathrm{mL}$ 미 만, $1.0-8.0 \mathrm{ng} / \mathrm{mL}$ 및 $8.0 \mathrm{ng} / \mathrm{mL}$ 초과의 세 군으로 구분하였고, 정도관리물질 제조 전까지 냉동 $\left(-20^{\circ} \mathrm{C}\right)$ 하였다. 본 연구는 (재)서 울의과학연구소 기관생명심의위원회로부터 심의(2018-50-01F) 를 득한 후 진행되었다.

\section{Anti-Müllerian hormone 정도관리물질 제조}

냉동된 개별 혈청을 실온에서 해동한 후 각 세 군의 농도에 해당 하는 검체끼리 혼합하고 멸균거즈에 걸러 섬유소를 제거하였다. 세 가지 다른 농도의 혼주혈청 각 $30 \mathrm{~mL}$ 에 $10 \%$ sodium azide (Sigma-Aldrich, St. Louis, MO, USA) 용액을 $1 \%$ 농도로 첨가 후 교반기에서 $180 \mathrm{rpm}$ 의 속도로 10 분간 혼합하였다. 제조된 세
농도의 정도관리물질을 각 $1.0 \mathrm{~mL}$ 씩 멸균된 $2.0 \mathrm{~mL}$ Cryogenic vial (Corning Life Science, Corning, NY, USA)에 분주하여 뚜 껑을 닫고 파라핀 필름으로 봉한 후 다시 냉동하여 $\left(-20^{\circ} \mathrm{C}\right)$ 보관하 였다.

\section{3. 검사방법}

$\mathrm{AMH}$ 검사는 UniCel DxI 800 Access (Beckman Coulter Inc., Brea, CA, USA) 장비를 이용하여 화학발광면역검사(chemiluminescent immunoassay)로 측정하였다. Access AMH 검사의 분석측정범위는 $0.08-24.0 \mathrm{ng} / \mathrm{mL}$ 이며, $0.16 \mathrm{ng} / \mathrm{mL}$ 이상의 농도에서 총 비정밀도(total imprecision)는 $10.0 \%$ 미 만인 것으로 시약 설명서에 제시되어 있다. 건강한 성인 여성에 서 AMH 농도는 연령이 증가할수록 감소되며, 각 연령범위에 따 른 참고치는 다음과 같다: $18-25$ 세, $1.02-14.63 \mathrm{ng} / \mathrm{mL} ; 26-30$ 세, $0.69-13.39 \mathrm{ng} / \mathrm{mL}$; 31-35세, $0.36-10.07 \mathrm{ng} / \mathrm{mL} ; 36-40$ 세, $0.18-5.68 \mathrm{ng} / \mathrm{mL} ; 41-45$ 세, $0.01-2.99 \mathrm{ng} / \mathrm{mL}$. B형 간 염 표면항원검사는 Cobas e602 (Roche Diagnostics $\mathrm{GmbH}$, Mannheim, Germany)를 이용하여 전자화학발광 면역분석 법(electro-chemiluminescent immunoassay)으로 검사 하였다. C형 간염 항체와 HIV 항체검사는 ARCHITECT i2000 (Abbott Laboratories, Abbott Park, IL, USA)을 이용하여 화학 발광 미세입자 면역분석법(chemiluminescent microparticle immunoassay)으로 검사하였다. 냉동된 $\mathrm{AMH}$ 정도관리물질은 측정 전 실온 $\left(20^{\circ} \mathrm{C}-25^{\circ} \mathrm{C}\right)$ 에서 해동 후 교반기를 이용, 검사 시행 전 충분히 혼합하였다. 연구에 사용된 $\mathrm{AMH}$ 검사는 모두 한 시약 lot로 검사하였고, 해당 lot를 사용하기 전 장비 보정을 시행하였다.

\section{4. 연구기간 중 anti-Müllerian hormone 검사의 내부정 도관리}

연구기간 중 $\mathrm{AMH}$ 검사의 내부정도관리방법으로, 매 검사 전 세 농도의 전용 정도관리물질인 Access AMH QC (QC lot 789214; Beckman Coulter Inc.)를 사용하여 내부정도관리를 시행하였 다(Table 1). 내부정도관리의 target value 설정방법으로, 새로운 lot의 정도관리물질 사용 시 각 농도의 정도관리물질의 5 회 반복 측정한 결과의 평균과 기존 사용 중인 표준편차를 적용하다가, 새 lot에 대한 결과가 20회 이상 누적되면 해당 lot에 대한 평균과 표 준편차를 재설정하여 적용하였다. 매 실험 시 내부정도관리 결과 가 QC target 범위 이내에 들어감을 확인한 후 실험을 진행하였다.

\section{Anti-Müllerian hormone 정도관리물질의 용기 간 균 질성 평가 \\ $\mathrm{AMH}$ 정도관리물질이 용기 간 균질하게 제조되었는지 확인하}


기 위하여 level I, II 및 III 각 세 농도의 정도관리물질을 5 개씩 임 의로 선택하여 $\mathrm{AMH}$ 농도를 3회씩 반복 측정하였다. 측정된 결 과치에 대해 각 농도별로 일원배치분산분석(one way analysis of variance)을 시행하였고, ISO (International Organization for Standardization) guide 35에 준하여 농도별 용기 간 표준 편차(between-vial standard deviation)와 재현성 표준편차 (repeatability standard deviation) 값을 구하여 평가하였다 [5]. 통계분석에는 MedCalc ver. 19.4.1 (MedCalc Software, Ostend, Belgium)를 사용하였다.

\section{Anti-Müllerian hormone 정도관리물질의 보관온도 및 보관기간에 따른 단기 안정성 평가}

$\mathrm{AMH}$ 정도관리물질의 보관온도와 보관기간에 따른 단기 안정 성 평가방법으로 각 세 level의 정도관리물질을 냉동 $\left(-20^{\circ} \mathrm{C}\right)$, 냉 장 $\left(4^{\circ} \mathrm{C}\right)$ 및 실온 $\left(20^{\circ} \mathrm{C}\right)$ 의 조건에서 제조 직후, 1 일, 2 일, 3 일 및 7
일 경과 후 AMH 농도를 2회씩 반복 측정하였다. 각 세 level에 대 하여 온도 및 보관기간에 따른 $\mathrm{AMH}$ 농도의 평균, 표준편차와 변 이계수를 구하였다. 또한 각 level별로 보관온도에 따른 검사일 내 변이계수(within-day coefficient of variation), 검사일 간 변 이계수(between-day coefficient of variation) 및 총 변이계수 (total coefficient of variation)를 구하였다.

\section{결과}

\section{1. 연구기간 anti-Müllerian hormone 검사의 내부정도} 관리 결과

$\mathrm{AMH}$ 외부정도관리물질의 균질도 및 안정성 시험을 진행한 8 일 동안의 $\mathrm{AMH}$ 내부정도관리 결과는 세 농도의 내부정도관리물질에 대하여 변이계수 4.46\%-6.80\% 사이로 안정적이었다(Table 1).

Table 1. Results of the internal QC testing for anti-Müllerian hormone to assess the homogeneitiy and stability during the evaluation period

\begin{tabular}{|c|c|c|c|c|c|c|}
\hline \multirow{2}{*}{ QC materials } & \multicolumn{2}{|c|}{ QC target } & \multicolumn{2}{|c|}{ During 1 month } & \multicolumn{2}{|c|}{$\begin{array}{l}5 \text { Testing days during } \\
\text { 8-day evaluation }\end{array}$} \\
\hline & Mean (ng/mL) & Range (ng/mL) & Mean $\pm \mathrm{SD}(\mathrm{ng} / \mathrm{mL})$ & CV (\%) & Mean $\pm \mathrm{SD}(\mathrm{ng} / \mathrm{mL})$ & CV (\%) \\
\hline $\mathrm{QC1}$ & 1.02 & $0.86-1.18$ & $0.96 \pm 0.06$ & 6.74 & $0.97 \pm 0.07$ & 6.80 \\
\hline QC2 & 5.17 & $4.29-6.05$ & $4.97 \pm 0.33$ & 6.54 & $5.02 \pm 0.27$ & 5.31 \\
\hline QC3 & 15.44 & $13.42-17.46$ & $14.98 \pm 0.91$ & 6.10 & $14.77 \pm 0.66$ & 4.46 \\
\hline
\end{tabular}

Abbreviations: QC, quality control; SD, standard deviation; CV, coefficient of variation.

Table 2. Homogeneity assessment for three levels of AMH EQA materials

\begin{tabular}{|c|c|c|c|c|c|c|}
\hline \multirow{2}{*}{ Vial no. } & \multicolumn{2}{|l|}{ Level I } & \multicolumn{2}{|c|}{ Level II } & \multicolumn{2}{|c|}{ Level III } \\
\hline & Mean $\pm S D(n g / m L)$ & CV (\%) & Mean $\pm S D(n g / m L)$ & CV (\%) & Mean $\pm \mathrm{SD}(\mathrm{ng} / \mathrm{mL})$ & CV (\%) \\
\hline Vial $1(n=3)$ & $0.49 \pm 0.02$ & 3.53 & $5.77 \pm 0.03$ & 0.50 & $9.76 \pm 0.19$ & 1.99 \\
\hline Vial $2(n=3)$ & $0.49 \pm 0.01$ & 1.19 & $5.91 \pm 0.13$ & 2.20 & $9.48 \pm 0.03$ & 0.28 \\
\hline Vial $3(n=3)$ & $0.51 \pm 0.01$ & 2.28 & $5.61 \pm 0.13$ & 2.23 & $9.61 \pm 0.25$ & 2.57 \\
\hline Vial $4(n=3)$ & $0.48 \pm 0.01$ & 2.42 & $5.65 \pm 0.18$ & 3.15 & $9.32 \pm 0.28$ & 2.98 \\
\hline Vial $5(n=3)$ & $0.49 \pm 0.01$ & 1.17 & $6.02 \pm 0.08$ & 1.38 & $9.78 \pm 0.33$ & 3.34 \\
\hline Overall $(n=15)$ & $0.49 \pm 0.01$ & 2.12 & $5.93 \pm 0.11$ & 1.89 & $9.78 \pm 0.33$ & 2.23 \\
\hline Total CV (\%) & \multicolumn{2}{|l|}{2.91} & \multicolumn{2}{|l|}{2.40} & \multicolumn{2}{|l|}{2.80} \\
\hline$P$-value* & \multicolumn{2}{|l|}{0.0839} & \multicolumn{2}{|c|}{0.1582} & \multicolumn{2}{|l|}{0.1832} \\
\hline $\mathrm{S}_{b b}$ & \multicolumn{2}{|c|}{$0.009 \mathrm{ng} / \mathrm{mL}(1.78 \%)$} & \multicolumn{2}{|c|}{$0.073 \mathrm{ng} / \mathrm{mL}(1.26 \%)$} & \multicolumn{2}{|c|}{$0.132 \mathrm{ng} / \mathrm{mL}(1.38 \%)$} \\
\hline $\mathrm{S}_{\mathrm{r}}$ & \multicolumn{2}{|c|}{$0.011 \mathrm{ng} / \mathrm{mL}(2.29 \%)$} & \multicolumn{2}{|c|}{$0.122 \mathrm{ng} / \mathrm{mL}(2.09 \%)$} & \multicolumn{2}{|c|}{$0.238 \mathrm{ng} / \mathrm{mL}(2.48 \%)$} \\
\hline
\end{tabular}

Abbreviations: $\mathrm{AMH}$, anti-Müllerian hormone; EQA, external quality assurance; SD, standard deviation; $\mathrm{CV}$, coefficient of variation; $\mathrm{S}_{b b}$, between-vial standard deviation; $S_{r}$, repeatability standard deviation.

*Significant results with $P$-values less than 0.05 (by analysis of variance). 


\section{Anti-Müllerian hormone 정도관리물질의 균질성 평 가결과}

$\mathrm{AMH}$ 정도관리물질의 용기간 균질성 평가에서 level별 각 5 개 용기에 대한 3회 반복검사의 총 변이계수는 다음과 같았다: level I, 2.91\% (mean AMH, $0.49 \mathrm{ng} / \mathrm{mL}$ ); level II, 2.40\% (mean AMH, $5.93 \mathrm{ng} / \mathrm{mL}$ ); level III, 2.80\% (mean AMH, $9.78 \mathrm{ng} /$ $\mathrm{mL}$ ). 세 level 모두 용기 간 표준편차인 $\mathrm{S}_{b b}$ 값이 재현성 표준편차 인 $\mathrm{S}_{\mathrm{r}}$ 값에 비하여 낮은 결과를 보여 불균질도가 없는 것으로 평가
되었다(Table 2).

\section{Anti-Müllerian hormone 정도관리물질의 보관온도 및 기간에 따른 단기 안정성 평가결과}

냉동 및 냉장온도에서 제조된 정도관리물질을 7 일까지 보관 시 각 세 농도의 총 변이계수는 각각 $5.98 \%-7.13 \%$ 및 4.85\%$8.40 \%$ 의 범위로, 시약사에서 제시한 총 비정밀도 $10.0 \%$ 이내의 결과를 보였다. 반면, 실온보관 시 level I의 총 변이계수는 $7.40 \%$

Table 3. AMH concentration after storage under three different conditions $\left(4^{\circ} \mathrm{C}, 20^{\circ} \mathrm{C}\right.$, and $\left.-4^{\circ} \mathrm{C}\right)$ on days $1,2,4$, and 7

\begin{tabular}{|c|c|c|c|c|c|c|c|c|c|c|c|}
\hline \multirow[b]{2}{*}{ Level } & \multirow[b]{2}{*}{$\begin{array}{c}\text { Storage } \\
\text { condition } \\
\left({ }^{\circ} \mathrm{C}\right)\end{array}$} & \multirow[b]{2}{*}{ Category } & \multicolumn{9}{|c|}{ AMH stability test } \\
\hline & & & $\begin{array}{l}\text { Day } 0 \\
(n=2)\end{array}$ & $\begin{array}{l}\text { Day } 1 \\
(n=2)\end{array}$ & $\begin{array}{l}\text { Day } 2 \\
(n=2)\end{array}$ & $\begin{array}{l}\text { Day } 4 \\
(n=2)\end{array}$ & $\begin{array}{l}\text { Day } 7 \\
(n=2)\end{array}$ & $\begin{array}{c}\text { Overall } \\
(n=10)\end{array}$ & $\begin{array}{l}\text { Within- } \\
\text { day CV } \\
(\%)\end{array}$ & $\begin{array}{c}\text { Between- } \\
\text { day CV } \\
(\%)\end{array}$ & $\begin{array}{c}\text { Total } \\
\text { CV (\%) }\end{array}$ \\
\hline \multirow[t]{9}{*}{1} & -20 & Mean (ng/mL) & 0.51 & 0.51 & 0.48 & 0.47 & 0.43 & 0.48 & 2.57 & 6.65 & 7.13 \\
\hline & & $\mathrm{SD}(\mathrm{ng} / \mathrm{mL})$ & 0.01 & 0.02 & 0.00 & 0.01 & 0.01 & 0.03 & & & \\
\hline & & CV (\%) & 1.40 & 4.20 & 0.00 & 3.01 & 1.66 & 6.78 & & & \\
\hline & 4 & Mean (ng/mL) & 0.51 & 0.49 & 0.47 & 0.46 & 0.45 & 0.47 & 0.94 & 4.75 & 4.85 \\
\hline & & $\mathrm{SD}(\mathrm{ng} / \mathrm{mL})$ & 0.01 & 0.00 & 0.01 & 0.00 & 0.00 & 0.02 & & & \\
\hline & & CV (\%) & 1.40 & 0.00 & 1.52 & 0.00 & 0.00 & 4.58 & & & \\
\hline & 20 & Mean (ng/mL) & 0.51 & 0.49 & 0.47 & 0.43 & 0.43 & 0.46 & 0.96 & 7.33 & 7.40 \\
\hline & & $\mathrm{SD}(\mathrm{ng} / \mathrm{mL})$ & 0.01 & 0.00 & 0.01 & 0.00 & 0.00 & 0.03 & & & \\
\hline & & CV (\%) & 1.40 & 0.00 & 1.52 & 0.00 & 0.00 & 6.98 & & & \\
\hline \multirow[t]{9}{*}{ II } & -20 & Mean (ng/mL) & 6.67 & 6.10 & 6.20 & 5.77 & 5.85 & 6.11 & 2.00 & 5.64 & 5.98 \\
\hline & & $\mathrm{SD}(\mathrm{ng} / \mathrm{mL})$ & 0.16 & 0.21 & 0.08 & 0.01 & 0.02 & 0.35 & & & \\
\hline & & CV (\%) & 2.44 & 3.36 & 1.26 & 0.12 & 0.36 & 5.68 & & & \\
\hline & 4 & Mean (ng/mL) & 6.67 & 6.51 & 6.01 & 5.49 & 5.77 & 6.09 & 2.85 & 7.90 & 8.40 \\
\hline & & $\mathrm{SD}(\mathrm{ng} / \mathrm{mL})$ & 0.16 & 0.08 & 0.26 & 0.16 & 0.15 & 0.49 & & & \\
\hline & & CV (\%) & 2.44 & 1.30 & 4.36 & 2.97 & 2.58 & 7.98 & & & \\
\hline & 20 & Mean (ng/mL) & 6.67 & 6.06 & 5.76 & 5.29 & 5.09 & 5.77 & 2.31 & 10.80 & 11.00 \\
\hline & & $\mathrm{SD}(\mathrm{ng} / \mathrm{mL})$ & 0.16 & 0.23 & 0.08 & 0.06 & 0.01 & 0.60 & & & \\
\hline & & CV (\%) & 2.44 & $3.7 \%$ & 1.47 & 1.20 & 0.14 & 10.44 & & & \\
\hline \multirow[t]{9}{*}{ III } & -20 & Mean (ng/mL) & 10.71 & 10.30 & 10.11 & 9.13 & 9.31 & 9.91 & 2.47 & 6.53 & 6.98 \\
\hline & & $\mathrm{SD}(\mathrm{ng} / \mathrm{mL})$ & 0.11 & 0.32 & 0.03 & 0.37 & 0.21 & 0.66 & & & \\
\hline & & CV (\%) & 0.99 & 3.09 & 0.28 & 4.11 & 2.28 & 6.64 & & & \\
\hline & 4 & Mean (ng/mL) & 10.71 & 9.94 & 9.85 & 9.23 & 9.08 & 9.76 & 1.92 & 6.50 & 6.78 \\
\hline & & $\mathrm{SD}(\mathrm{ng} / \mathrm{mL})$ & 0.11 & 0.13 & 0.02 & 0.22 & 0.31 & 0.63 & & & \\
\hline & & CV (\%) & 0.99 & 1.35 & 0.22 & 2.38 & 3.43 & 6.42 & & & \\
\hline & 20 & Mean (ng/mL) & 10.71 & 10.48 & 9.48 & 8.48 & 8.54 & 9.54 & 1.88 & 10.89 & 11.05 \\
\hline & & $\mathrm{SD}$ (ng/mL) & 0.11 & 0.35 & 0.08 & 0.06 & 0.12 & 1.00 & & & \\
\hline & & CV (\%) & 0.99 & 3.37 & 0.90 & 0.67 & 1.41 & 10.44 & & & \\
\hline
\end{tabular}

Abbreviations: AMH, Anti-Müllerian hormone; CV, coefficient of variation; SD, standard deviation. 
였으나 level II와 level III는 각각 $11.00 \%$ 와 $11.05 \%$ 로 시약사에 서 제시한 총 비정밀도 $10.0 \%$ 를 초과하였다(Table 3).

\section{고찰}

$\mathrm{AMH}$ 측정을 위한 검사방법으로 ELISA 검사법이 1990년에 보 고된 이후 $\mathrm{AMH}$ 의 면역검사가 지속적으로 개발되어 왔고, 현재 는 자동화면역검사법이 널리 도입되어 임상검사에 사용되고 있다 [6]. 자동화장비의 도입으로 $\mathrm{AMH}$ 검사의 정밀도와 검사 효율성이 크게 향상되었으나 장비•시약 간에 농도 차이를 보이는 등의 문 제점이 제기되었다[7-9]. 예를 들어 기존 ELISA 방법(AMH Gen II)과 비교하여 Access AMH는 약 15\%, Elecsys AMH (Roche Diagnostics $\mathrm{GmbH}$ )는 약 $20 \%-30 \%$ 차이를 보이는 것으로 보 고되었다[9]. 여성의 연령별 $\mathrm{AMH}$ 참고치가 시약제조사에 따라 다르며, $\mathrm{AMH}$ 의 임상적 기준치도 문헌에 따라 차이가 있다. $\mathrm{AMH}$ 농도의 방법 간 차이는 검사시약에 사용되는 항체 특이성의 차 이, 소급성의 결여, 개체 간(inter-individual) 및 개체 내(intraindividual) 차이, 검사 전 요인 등이 복합적으로 작용하여 초래될 수 있다[10]. AMH 검사의 진단적 효율성을 높이기 위해서는 내부 정도관리 외에 외부정도관리 프로그램을 통한 면밀한 질 관리가 필수적이며, 궁극적으로 AMH 검사의 표준화(standardization) 와 일치화(harmonization)가 이루어져야 할 필요가 있다.

초기에 $\mathrm{AMH}$ 의 경우 $\mathrm{FSH}$ 와 같은 다른 성호르몬과 달리 생리주 기에 따른 변이가 거의 없이 일정한 농도를 보인다는 점이 큰 장 점으로 부각되었지만, 최근 연구에 의하면 $\mathrm{AMH}$ 의 평균적인 총 개체 내 변이(total intra-individual variation)는 20\% (range, 2.1\%-73\%) 정도로 크며, 임상적 기준치 근처에 해당하는 저농도 에서 시약 간 $\mathrm{AMH}$ 농도 차이가 더욱 큰 문제점이 지적되었다[11]. $\mathrm{AMH}$ 검사 시 검체의 불안정성 문제도 지적된 바 있는데, Zuvela 등[12]은 호주에서 2011년 도입한 AMH 외부신빙도조사 결과 에서 각 검사실의 재현성은 우수하지만 기준 농도(consensus value)와의 차이가 $-27.9 \%$ 에서 $54.7 \%$ 로 검사실 간 차이가 매 우 컸다고 보고하였다. $\mathrm{AMH}$ 의 검사실 간 큰 편차는 검사방법 및 시약 차이뿐 아니라 $\mathrm{AMH}$ 의 검체 안정성 문제 등 복합적인 요인 이 작용한 결과일 수 있다. $\mathrm{AMH}$ 는 혈청에 비하여 전혈에서 단백 분해가 더욱 신속히 일어나 불안정하므로 시약제조사(Beckman Coulter Inc.)에서는 검체 채취 후 원심분리를 통하여 가급적 신 속하게 혈청·혈장을 분리할 것을 권장하고 있다. 제조사가 제시 하고 있는 혈청·혈장의 안정성은 실온 $\left(15^{\circ} \mathrm{C}-30^{\circ} \mathrm{C}\right)$ 에서 24 시간, 냉장 $\left(2^{\circ} \mathrm{C}-8^{\circ} \mathrm{C}\right)$ 에서 6 일 이내이다. 혈청에서 $\mathrm{AMH}$ 의 안정성에 대 한 연구들은 상반된 결과들을 보여주고 있다. Rustamov 등[13] 은 혈청을 냉동 $\left(-20^{\circ} \mathrm{C}\right)$ 하여 5 일 보관 후 냉동 전에 비하여 $\mathrm{AMH}$
농도가 $23 \%$ 증가하였다고 한 반면, Kumar 등[14]은 혈청의 냉 장보관 $\left(2^{\circ} \mathrm{C}-8^{\circ} \mathrm{C}\right)$ 시 7 일까지 안정적이었다고 보고하였다. 또한 Fleming 등[15]은 5 시간 이내에 분리된 혈청의 실온보관 $\left(20^{\circ} \mathrm{C}\right)$ 시 7일까지도 변화가 없었다고 하였다.

검사방법·시약에 따른 $\mathrm{AMH}$ 안정성의 차이는 각 시약에 사용 된 항체의 특이성 차이로 인한 $\mathrm{AMH}$ isoform의 검출능 차이에 기 인할 수 있다[10]. AMH는 크기가 작은 전정난포의 난포액에 고 농도로 축적되는데, 동일한 두 개의 모노머 소단위가 이황결합으 로 연결된 $140 \mathrm{kDa}$ 의 전구체(proAMH) 형태로 합성된다. 각 모 노머 소단위는 C-말단 도메인(mature region)과 $\mathrm{N}$-말단 도메인 (pre region)을 포함하며, 세포질 통과 중 $\mathrm{AMH}$ 분자의 다양한 부 위가 단백질분해로 절단되어 활성화된다[16]. 미성숙 과립층세포 내부에 다양한 $\mathrm{AMH}$ isoform이 존재함이 확인되었으며, $\mathrm{AMH}$ 의 분해는 혈액 내에서도 진행되고, 혈액에 적어도 네 가지(proAMH, $\mathrm{AMH}_{\mathrm{N}, \mathrm{C}}$, dissociated fragment 및 mature fragment)의 $\mathrm{AMH}$ isoform이 순환하고 있다 $[17,18]$. 혈액에서 $\mathrm{AMH}$ 의 분해과정에 대하여 현재까지 밝혀진 내용은 매우 한정적이며, 월경주기에 걸 쳐 다른 분자형태의 $\mathrm{AMH}$ 가 생성되고, $\mathrm{AMH}$ isoform의 profile 이 개체 간 $\mathrm{AMH}$ 변이와도 관련될 수 있을 것이라 추정되고 있다. $\mathrm{AMH}$ 의 단백질 분해가 진행되면 구조 변화가 일어나고 새로운 항 원 결정인자가 노출되면서 항체에 대한 친화력의 변화가 일어나 게 된다[19]. 최근 다낭성 난소증후군 대상 연구에서 $\mathrm{AMH}$ 검사에 사용되는 항체의 특이성 차이가 AMH 분자 epitope의 인식 차이, 친화력의 차이를 유발하고, 따라서 시약에 따라 검출되는 $\mathrm{AMH}$ 의 isoform에 차이가 있다고 보고된 바 있다[19,20].

본 연구에서 정도관리물질 제조 시 혼주혈청의 혼합방법으로 교반기에서 $180 \mathrm{rpm}$ 의 속도로 10 분간 혼합하였고, 세 level의 정 도관리물질 모두 용기 간 $\mathrm{AMH}$ 농도에 유의한 차이가 없이 균질하 게 제조된 것으로 평가되었다. Cholesterol에 대한 이차 참고물질 로서 교환성 냉동 혈청(commutable frozen serum)을 만들기 위한 지침인 Clinical Laboratory Standard Institute 37-A에서 는 혼주혈청의 혼합 시 $4^{\circ} \mathrm{C}$ 에서 18 시간 동안 저속으로 혼합할 것 을 권장하고 있다[21]. 하지만 이 지침은 헌혈된 혈액에서 혈청을 분리하여 비교적 안정성이 높은 cholesterol과 같은 정도관리물 질의 제조에 적합한 방법으로 생각된다. 수집된 잔여 혈청을 이용 하여 상대적으로 안정성이 낮은 $\mathrm{AMH}$ 의 정도관리물질 제조 시에 도 동일한 혼합방법을 적용해도 문제가 없을지 추가연구가 필요하 다고 생각된다.

단기 안정성 평가실험에서 실온보관 시 정도관리물질의 level 에 따라 차이를 보였는데, 가능한 원인으로 혼주혈청 제조 시 포함 된 개별 혈청들의 AMH isoform 비율이 제조된 level에 따라 차이 가 있을 수 있고, 결국 단백분해 속도 차이와도 연관될 수 있다고 
추정된다. 정도관리물질의 냉장보관 $\left(4^{\circ} \mathrm{C}\right)$ 및 냉동보관 $\left(-20^{\circ} \mathrm{C}\right)$ 시 에는 7일까지의 안정성이 허용범위 이내인 것으로 평가되었다.

$\mathrm{AMH}$ 검사의 표준화•일치화에 대한 지속적인 요구에 부응하

여 National Institute for Biological Standards and Control (NIBSC, Ridge, UK)에서 World Health Organization의 지원하 에 $\mathrm{AMH}$ 에 대한 국제표준물질을 만들기 위한 노력이 진행되어왔 고[22], 2019년 11월 처음으로 AMH 국제표준물질(NIBSC code: $16 / 190)$ 이 생산되었다. 이에 발맞추어 국내에서도 AMH 외부정도 관리가 2020년 상반기부터 시행되기 시작하였다. 향후 AMH 검사
의 표준화•일치화를 위한 노력과 더불어 임상적으로 통용되는 기 준치 설정이 된다면 $\mathrm{AMH}$ 검사의 진단적 효율성이 현저히 향상될 수 있을 것으로 기대한다.

\section{감사의 글}

이 논문은 대한임상검사정도관리협회 2018년 학술연구비 지원 에 의해 수행되었다.

\section{REFERENCES}

1. Carlsson IB, Scott JE, Visser JA, Ritvos O, Themmen AP, Hovatta O. Anti-Mullerian hormone inhibits initiation of growth of human primordial ovarian follicles in vitro. Hum Reprod 2006;21:2223-7.

2. Nelson SM. Biomarkers of ovarian response: current and future applications. Fertil Steril 2013;99:963-9.

3. Broer SL, Broekmans FJ, Laven JS, Fauser BC. Anti-Mullerian hormone: ovarian reserve testing and its potential clinical implications. Hum Reprod Update 2014;20:688-701.

4. Leader B, Baker VL. Maximizing the clinical utility of antimullerian hormone testing in women's health. Curr Opin Obstet Gynecol 2014;26:226-36.

5. Ellison SL. Homogeneity studies and ISO guide 35:2006. Accred Qual Assur 2015;20:519-28.

6. Tadros T, Tarasconi B, Nassar J, Benhaim JL, Taieb J, Fanchin R. New automated antimullerian hormone assays are more reliable than the manual assay in patients with reduced antral follicle count. Fertil Steril 2016;106:1800-6.

7. Rustamov O, Smith A, Roberts SA, Yates AP, Fitzgerald C, Krishnan M, et al. The measurement of anti-Mullerian hormone: a critical appraisal. J Clin Endocrinol Metab 2014;99:723-32.

8. Hyldgaard J, Bor P, Ingerslev HJ, Torring N. Comparison of two different methods for measuring anti-Mullerian hormone in a clinical series. Reprod Biol Endocrinol 2015;13:107.

9. Iliodromiti S, Salje B, Dewailly D, Fairburn C, Fanchin R, Fleming R, et al. Non-equivalence of anti-Mullerian hormone automated assays-clinical implications for use as a companion diagnostic for individualised gonadotrophin dosing. Hum Reprod 2017;32:1710-5.

10. Bungum L, Tagevi J, Jokubkiene L, Bungum M, Giwercman A, Macklon N, et al. The impact of the biological variability or assay performance on AMH measurements: a prospective cohort study with AMH tested on three analytical assay-platforms. Front Endocrinol (Lausanne) 2018;9:603.

11. Hadlow N, Brown SJ, Habib A, Wardrop R, Joseph J, Gillett M, et al Quantifying the intraindividual variation of antimullerian hormone in the ovarian cycle. Fertil Steril 2016;106:1230-7.

12. Zuvela E, Walls M, Matson P. Within-laboratory and between-laboratory variability in the measurement of antiMullerian hormone determined within an external quality assurance scheme. Reprod Biol 2013;13:255-7.

13. Rustamov O, Smith A, Roberts SA, Yates AP, Fitzgerald C, Krishnan M, et al. Anti-Mullerian hormone: poor assay reproducibility in a large cohort of subjects suggests sample instability. Hum Reprod 2012;27:3085-91.

14. Kumar A, Kalra B, Patel A, McDavid L, Roudebush WE. Development of a second generation anti-Mullerian hormone (AMH) ELISA. J Immunol Methods 2010;362:51-9.

15. Fleming R, Fairbairn C, Blaney C, Lucas D, Gaudoin M. Stability of AMH measurement in blood and avoidance of proteolytic changes. Reprod Biomed Online 2013;26:130-2. 
16. Pepinsky RB, Sinclair LK, Chow EP, Mattaliano RJ, Manganaro TF, Donahoe PK, et al. Proteolytic processing of Mullerian inhibiting substance produces a transforming growth factor-beta-like fragment. J Biol Chem 1988;263:18961-4.

17. Mamsen LS, Petersen TS, Jeppesen JV, Mollgard K, Grondahl ML, Larsen A, et al. Proteolytic processing of antiMullerian hormone differs between human fetal testes and adult ovaries. Mol Hum Reprod 2015;21:571-82.

18. Pankhurst MW, Chong YH. Variation in circulating antimullerian hormone precursor during the periovulatory and acute postovulatory phases of the human ovarian cycle. Fertil Steril 2016;106:1238-43.

19. Wissing ML, Mikkelsen AL, Kumar A, Kalra B, Pors SE, Flachs EM, et al. Associations of different molecular forms of antimullerian hormone and biomarkers of polycystic ovary syndrome and normal women. Fertil Steril 2019;112:149-55.

20. Pankhurst MW, Shorakae S, Rodgers RJ, Teede HJ, Moran LJ. Efficacy of predictive models for polycystic ovary syndrome using serum levels of two antimullerian hormone isoforms (proAMH and $\mathrm{AMH}_{\mathrm{N}, \mathrm{C}}$ ). Fertil Steril 2017;108:851-7.

21. National Committee for Clinical Laboratory Standards. Preparation and validation of commutable frozen human serum pools as secondary reference materials for cholesterol measurement procedures; approved guideline: C37-A. Wayne (PA): Clinical and Laboratory Standards Institute, 1999.

22. Ferguson JM, Pepin D, Duru C, Matejtschuk P, Donahoe PK, Burns CJ. Towards international standardization of immunoassays for Mullerian inhibiting substance/anti-Mullerian hormone. Reprod Biomed Online 2018;37:631-40. 